
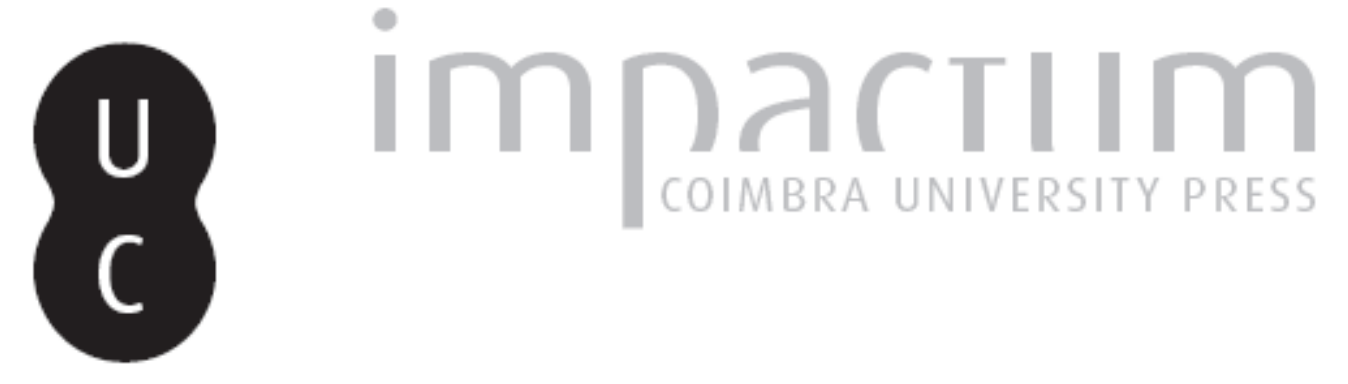

\title{
Entrevista a: Renato Rosaldo
}

Autor(es): Quintais, Luís

Publicado por: CIAS - Centro de Investigação em Antropologia e Saúde

URL persistente:

URl:http://hdl.handle.net/10316.2/29008

DOI:

DOI:http://dx.doi.org/10.14195/2182-7982_25_12

Accessed : $\quad$ 26-Apr-2023 14:48:53

A navegação consulta e descarregamento dos títulos inseridos nas Bibliotecas Digitais UC Digitalis, UC Pombalina e UC Impactum, pressupõem a aceitação plena e sem reservas dos Termos e Condições de Uso destas Bibliotecas Digitais, disponíveis em https://digitalis.uc.pt/pt-pt/termos.

Conforme exposto nos referidos Termos e Condições de Uso, o descarregamento de títulos de acesso restrito requer uma licença válida de autorização devendo o utilizador aceder ao(s) documento(s) a partir de um endereço de IP da instituição detentora da supramencionada licença.

Ao utilizador é apenas permitido o descarregamento para uso pessoal, pelo que o emprego do(s) título(s) descarregado(s) para outro fim, designadamente comercial, carece de autorização do respetivo autor ou editor da obra.

Na medida em que todas as obras da UC Digitalis se encontram protegidas pelo Código do Direito de Autor e Direitos Conexos e demais legislação aplicável, toda a cópia, parcial ou total, deste documento, nos casos em que é legalmente admitida, deverá conter ou fazer-se acompanhar por este aviso.

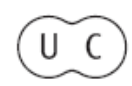




\section{Antropologia Portuguesa}

Volume $24-25 \cdot 2007-2008$

Departamento de Antropologia | Universidade de Coimbra

\section{Dossier Temático \\ CLAUDE LÉVI-STRAUSS}




\section{Renato Rosaldo}

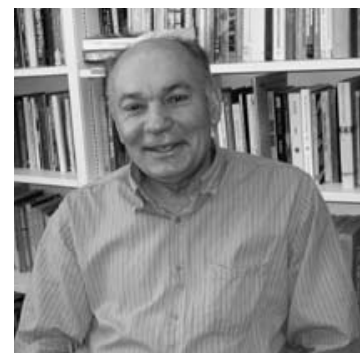

Department of Social and Cultural Analysis

Faculty of Arts \& Science

New York University

renato.rosaldo@nyu.edu

After many years at Stanford, Renato Rosaldo now teaches Anthropology at New York University. He is of Mexican descent and attended Tucson High School and received his B.A. and Ph.D. at Harvard. He was President of the American Ethnological Society, inaugural Director of Latino Studies at NYU, and is a member of the American Academy of Arts and Sciences. His books include Ilongot headhunting, 1883-1974, Culture and truth, and Renato Rosaldo: ensayos de antropología crítica. His first book of poetry, a bilingual Spanish-English collection entitled Prayer to spider woman/ Rezo a la mujer araña, won an American Book Award from the Before Columbus Foundation.

The conversation took place by an email exchange between Luís Quintais and Renato Rosaldo. This was done after Rosaldo's short visit to Coimbra in May 2008. We'd like to thank Professor Rosaldo for giving us his time and words.

Give us a general outline of your past and recent work.

My initial fieldwork was in the Philippines, among members of a hill tribe called the Ilongots. This period of research $(1967-69,1974)$ resulted in a historical ethnography entitled Ilongot Headhunting, 1883-1974, plus a series of essays reflecting on such matters as life history, oral history, and perceptions of tribal peoples that were mediated by colonial ideologies. I then became involved in the Chicano movement and multiculturalism. This took me in two directions. First, I began to reflect on the conceptual nature of ethnography in Culture and Truth. In that book I proposed that a new theoretical project had emerged in cultural anthropology that emphasized 
process and history (as opposed to the structural analysis of putatively unchanging societies) as well as social inequalities. I proposed that both the analyst and the members of the societies under study should be regarded as positioned subjects (rather than simply as detached observers). Second, I carried out a project on cultural citizenship in Chicana/o communities in the San Jose area of California. The idea of cultural citizenship concerns the notion of whether or not, and in what ways, the subjects have voice and are able to be heard, where and in what ways they have a sense of belonging. The notion of citizenship was more vernacular than official and it was a matter of degree (first versus second-class citizenship) than an either/or question. More recently I have been writing poetry as well as exploring the notion of cultural poetics, both as a form of analysis and as a mode of understanding the writing of ethnography.

In one of your essays, "Grief and a headhunter's rage", you describe experiences like bereavement which are, in sense, treated as if they were, by way of their disruptive qualities, immune to culture or untranslatable. I think that this is one of the most significant aspects of your work: you try to push anthropology to the limits of representation, and take that kind of liminar region (where "powerful visceral emotions" are impossible to circumvent) as a place where anthropology must inhabit if we want to know and experience the complexities and potentialities of cultures (which are not mere projections of our most common intellectually biased western traditions of thought). It seems that you are putting a sort of violence in the center of culture as a problem and a as concept. That reminds me also the work of your colleague and friend Michael Taussig. Could you please say more about that?

Yes, Taussig and I agree that the visceral, the disruptive, and the violent should be at the center of cultural analysis. Culture should not be limited to what is normal, routine, and expected. It may be that we should seek out the unexpected and the atypical as a way of apprehending other human lives. One example of this is what I call the problem of the vacant center in ethnography; that is, our failure to make present what is under study. In the case of a study of ideology one can imagine a study so focused on mechanisms of mystification and the class and other interests at play in the

${ }^{1}$ Rosaldo (1993 [1989]: 1-21). 
production of ideology that one fails to depict how the ideology persuades and mobilizes people to go into the streets. How does the ideology get people in its grip? At times, similarly, one can learn much about a society by exploring the perceptions of an odd person, an eccentric rather than a typical person or a central figure. Here I think of In the realm of the diamond queen by Anna Tsing. ${ }^{2}$

One of your essays that I first read was "From the door of his tent: the fieldworker and the inquisitor", included in the very influent Writing culture edited by Clifford and Marcus. ${ }^{3}$ What were the main preoccupations of that group of anthropologists and researchers at that time? Were they prepared to the enormous and uproarious reception that the book made? What are the influence of the cultural critique in which you were all involved then? Could we say that It transformed the face of anthropology in the transition of the century, or is this a very risky contention?

The preoccupations of the group involved in Writing culture (as well as the group involved in Women writing culture ${ }^{4}$ ) were problems of representation in ethnographic writing. The problem was that ethnographies were written in a kind of naive realism in which it was thought that the problems of methods all resided in data gathering or collection, and much thought was given to this matter of collection, but no attention was given to writing (which was seen as writing up, a seemingly transparent process, the less thought about the better). I personally thought that writing had come into crisis, not as a simple matter of experimentation, but rather because the analytical project of anthropology had shifted, with more attention being given to history and social inequalities, and that this changed analytical project meant that older forms of writing were no longer adequate almost to the point of seeming parodic. Thus, from the perspective of the newer analytical project the need for a change in, and more self-consciousness about, modes of writing fairly was screaming out for attention.

As you know our present volume of Antropologia Portuguesa is about Lévi-Strauss which will be 100 years old in November, 2008. We know that

\footnotetext{
${ }^{2}$ Tsing (1993).

${ }^{3}$ Clifford e Marcus (1986).

${ }^{4}$ Behar e Gordon (1996).
} 
structuralism is nowadays outdated, and, in my opinion, justly so. But we continue to return to his work. Why is he still so important for us?

Lévi-Strauss is still important to us because he most fully articulated the structuralist phase of anthropology and of intellectual thought more widely. He brought anthropology to the wider intellectual world, and showed the import of anthropology to the human sciences in general. He also articulated notions of cultural relativism in ways that grew deeply out of anthropological thought and carried this central message to the wider audience it always aspired to reach. The notion of relativism, of course, is the notion that simply because people do things differently does not mean that they are demented, stupid, or without morals; they simply operated with different assumptions and categories. It is not at all the notion that anything goes as ethnocentric thinkers declare in their rants against other forms of life.

\section{Bibliography}

Behar, R.; Gordon, D. A. (ed.). 1996. Women writing culture. Berkeley, University of California Press.

Rosaldo, R. 1986. From the door of his tent: the fieldworker and the inquisitor. In: Clifford, J; Marcus, G. (eds.). 1986. Writing culture: the poetics and politics of ethnography. Berkeley, Los Angeles, University of California Press: 77-97.

Rosaldo, R. 1993 (1989). Grief and a headhunter's rage. In: Culture and truth. London \& New York, Routledge: 1-21.

Tsing, A. L. 1993. In the realm of the diamond queen: marginality in an out-of-theway place. Princeton, Princeton University Press.

\section{Luís Quintais}

Departamento de Antropologia

Faculdade de Ciências e Tecnologia

Universidade de Coimbra

Ifgsq@antrop.uc.p 